\title{
Using ground-penetrating radar, topography and classification of vegetation to model the sediment and active layer thickness in a periglacial lake catchment, western Greenland
}

\author{
Johannes Petrone $^{1}$, Gustav Sohlenius ${ }^{2}$, Emma Johansson ${ }^{1,5}$, Tobias Lindborg ${ }^{1,3}$, Jens-Ove Näslund ${ }^{1,5}$, \\ Mårten Strömgren ${ }^{4}$, and Lars Brydsten ${ }^{4}$ \\ ${ }^{1}$ Swedish Nuclear Fuel and Waste Management Company, Box 250, 101 24, Stockholm, Sweden \\ ${ }^{2}$ Geological Survey of Sweden, Box 670, 751 28, Uppsala, Sweden \\ ${ }^{3}$ Department of Forest Ecology and Management, Swedish University of Agricultural Science, \\ 90183 Umeå, Sweden \\ ${ }^{4}$ Department of Ecology and Environmental Science, Umeå University, 90187 Umeå, Sweden \\ ${ }^{5}$ Department of Physical Geography, Stockholm University, 10691 Stockholm, Sweden
}

Correspondence to: Johannes Petrone (johannes.petrone@skb.se)

Received: 16 May 2016 - Published in Earth Syst. Sci. Data Discuss.: 5 July 2016

Revised: 23 September 2016 - Accepted: 30 October 2016 - Published: 23 November 2016

\begin{abstract}
The geometries of a catchment constitute the basis for distributed physically based numerical modeling of different geoscientific disciplines. In this paper results from ground-penetrating radar (GPR) measurements, in terms of a 3-D model of total sediment thickness and active layer thickness in a periglacial catchment in western Greenland, are presented. Using the topography, the thickness and distribution of sediments are calculated. Vegetation classification and GPR measurements are used to scale active layer thickness from local measurements to catchment-scale models. Annual maximum active layer thickness varies from $0.3 \mathrm{~m}$ in wetlands to $2.0 \mathrm{~m}$ in barren areas and areas of exposed bedrock. Maximum sediment thickness is estimated to be $12.3 \mathrm{~m}$ in the major valleys of the catchment. A method to correlate surface vegetation with active layer thickness is also presented. By using relatively simple methods, such as probing and vegetation classification, it is possible to upscale local point measurements to catchment-scale models, in areas where the upper subsurface is relatively homogeneous. The resulting spatial model of active layer thickness can be used in combination with the sediment model as a geometrical input to further studies of subsurface mass transport and hydrological flow paths in the periglacial catchment through numerical modeling. The data set is available for all users via the PANGAEA database, doi:10.1594/PANGAEA.845258.
\end{abstract}

1

\section{Introduction}

Recent climate warming, and its effect on near-surface hydrothermal regimes, is predicted to have a pronounced effect in northern latitudes (e.g., Maxwell and Barrie, 1989; Roots, 1989; MacCraken et al., 1990; Burrows et al., 2011; Larsen et al., 2014). In permafrost regions, where parts of the subsurface stay permanently frozen, one noticeable effect of global warming is a thickening of the active layer (Larsen et al.,
2014). The active layer constitutes an upper sediment and/or bedrock layer that undergoes annual freezing and thawing. Thickening of the active layer has biogeochemical, hydrological and geomorphological consequences due to the exchange of energy in the form of moisture and gases between the terrestrial and atmospheric system, which occurs in the thawed subsurface (Nelson and Anisimov, 1993; Weller et al., 1995). Additionally, a long-term thawing active layer may influence the carbon cycling in the landscape; old car- 
bon stored in the permafrost may be released, implying a positive feedback to climate warming (Walter et al., 2006; Schuur et al., 2015).

Dramatic changes in the Arctic during the last decades have, among other things, led to an increase in the length of the melting season and changes in precipitation patterns (Macdonald et al., 2005). To understand future local and regional effects of a warming climate in permafrost regions, it is first necessary to understand the present-day conditions and processes. Modeling the active layer and its variation, as well as any underlying sediments, is needed to account for different scenarios in which the active layer will vary in depth when surface conditions are changing. In addition, information regarding the properties and spatial distribution of the sediments and the active layer is valuable when studying the hydrology and mass transport in permafrost regions.

Conventional methods to identify permafrost features or bedrock under Quaternary deposits in permafrost regions, e.g., through boreholes or excavations, can be problematic and time-consuming due to the frozen conditions. In addition, such methods provide limited information on the spatial distribution of such features. Methods for investigating the spatial variability of the active layer include airborne electromagnetic measurements (e.g. Pastick et al., 2013), spaceborne interferometric synthetic aperture radar (InSAR) (e.g. Liu et al., 2012) and ground-penetrating radar (GPR) (e.g., Wu et al., 2009; Stevens et al., 2009). In this study we use GPR to investigate shallow sub-surface features, such as sediment thickness and the depth of the active layer. GPR surveying has been commonly used since the mid-1990s in geophysical studies that require high vertical resolution with little or no disturbance in the investigated area (Neal, 2004). The method is also very flexible, as real-time acquisition and interpretation of the data immediately give preliminary results. The suitability of the GPR method to map subsurface features in periglacial environments is due to the significantly different electrical properties between ice, water, sediment, bedrock and air. Relative dielectric permittivity is commonly used to determine the wave velocity of electromagnetic waves transmitted and received from the GPR. The dielectric permittivity is highly influenced by water content (Neal, 2004). It is therefore an effective method to map the permafrost boundary during summer as well as the subsurface bedrock (i.e., sediment thickness) when the sediments are frozen. Many studies using GPR in permafrost environments have been carried out (e.g., Wu et al., 2009; Stevens et al., 2009), as have studies using GPR to investigate the properties of the active layer (e.g., Ermakov and Starovoitov, 2010; Jørgensen and Andreasen, 2007; Doolitle et al., 1990; Gacitúa et al., 2012). Gacitúa et al. (2012) also showed that the difference in vegetation cover is closely tied to varying moisture content of sediments in periglacial environments.

The studies listed above, however, only focus on single and local profile investigations. The purpose of this study is to draw conclusions about subsurface conditions over larger areas, such as individual lake catchments. Here we use GPR to gather information about the relative dielectric permittivity (i.e., water content) of the sediments above the permafrost. The water content of the soil influences the composition of vegetation and the thickness of the active layer. A correlation between active layer thickness (ALT) and vegetation can therefore be expected. This correlation is used to construct a model of the spatial distribution and variation in the active layer and upscale results from concentrated measurements to a catchment-wide model.

In the present study we use GPR during different seasons to measure the depth to bedrock and ALT within a small lake catchment, in this paper referred to as Two Boat Lake (TBL), situated close to the Greenland Ice Sheet (Fig. 1). The sediment thickness within the catchment has been correlated to topography - i.e., the thickest sediment layers are found in flat areas of the valley floors (Petrone, 2013). This established relationship, in combination with field surveys and sampling, forms the basis for the construction of a model of sediment thickness and general stratigraphy. For the active layer we analyze the results in combination with probe measurements to estimate permittivity of the underlying sediments and with remote sensing to classify the vegetation. The relationship between vegetation and permittivity (Gacitúa et al., 2012) is used to calculate active layer depth for all GPR measurements. The result is a 3-D model of sediment thicknesses, sediment types and maximum thicknesses of the active layer, at catchment scale $\left(\sim 1-2 \mathrm{~km}^{2}\right)$. Data on meteorological and hydrological conditions and properties of the TBL catchment were published by Johansson et al. (2015), and Lindborg et al. (2016) published data on biogeochemistry from TBL. These new data on ALT and sediment thickness constitute valuable complementary input data when setting up distributed physically based hydrological and biogeochemical numerical models of the catchment. Since the active layer model is superimposed on the sediment model, it is also possible to study effects of a changing climate by varying the active layer depth. An increased depth of the active layer activates new hydrological flow paths above the present permafrost. The developed 3-D model presented in this study may constitute a geometrical input to other models studying the effect of those processes. By correlating different types of vegetation classes found in periglacial environments to subsurface wetness conditions, we construct models extending outside of the initial point measurements.

\section{Methods}

Field investigations were carried out between the years 2010 and 2013. The methodology was conducted stepwise, and each step is summarized in Fig. 2. The methods can be divided into two categories/models: one producing a catchment-wide coverage of the maximum active layer thickness and one focused on the stratigraphy and thickness of 


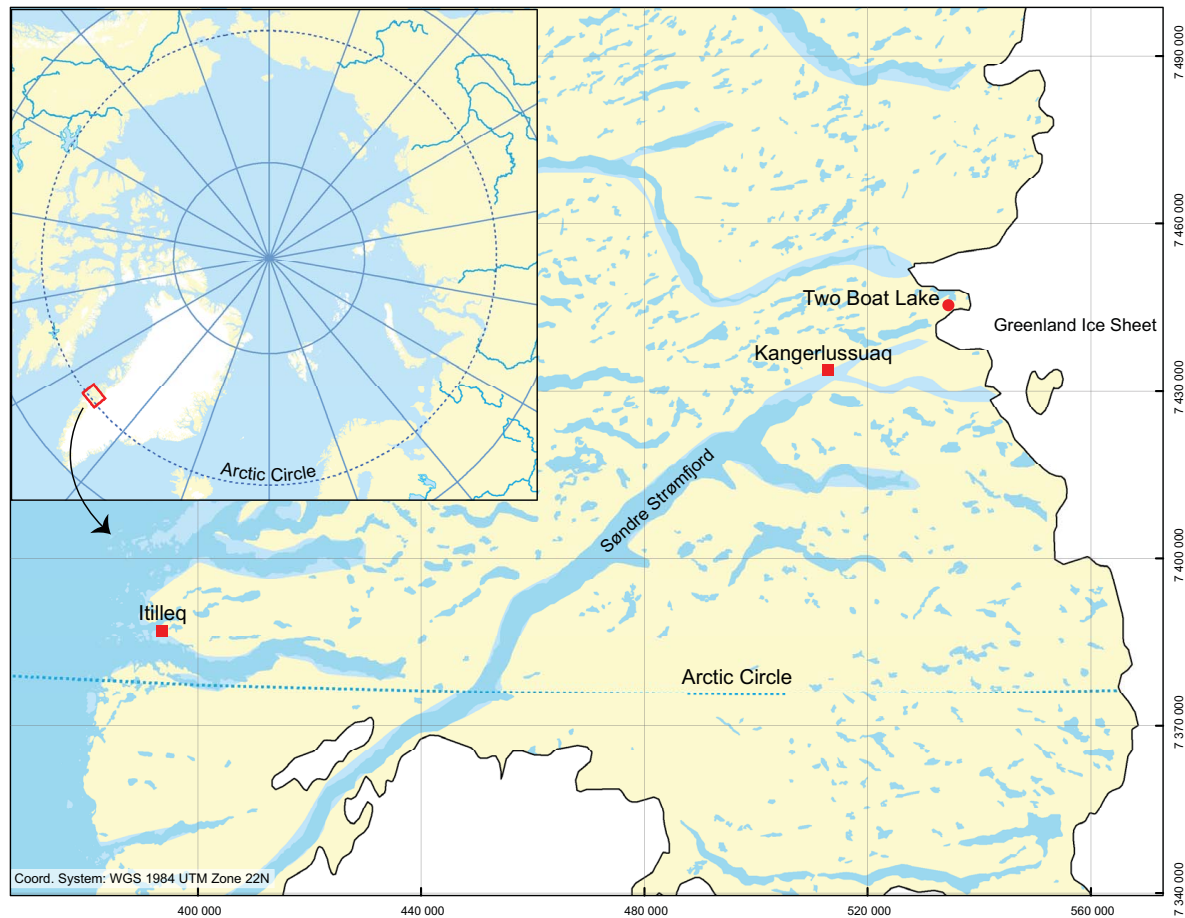

Figure 1. Map showing the location of the study site (Two Boat Lake), accessible from the nearby town of Kangerlussuaq (modified from Johansson et al., 2015).

Table 1. List of equipment and in which resulting model the data are used. DEM: digital elevation model; AL: active layer model; STM: sediment thickness model.

\begin{tabular}{llll}
\hline Parameter & Measurement technique & Model & Data origin \\
\hline Elevation & Lidar & DEM & Present paper \\
Lake bathymetry & Echo sounding & DEM & Present paper \\
Surface vegetation class & Aerial classification, field mapping & AL & Clarhäll (2011) \\
Surface sediment class & Sediment sampling, excavations, field mapping & STM & Clarhäll (2011) and present paper \\
Active layer depth & Probing, GPR & AL & Present paper \\
Depth to bedrock & GPR & STM & Present paper \\
\hline
\end{tabular}

the sediments. All field investigations were carried out in the catchment of TBL; a general site description is provided in Sect. 2.1.1 below, followed by a more detailed description of the Quaternary geology of the catchment in Sect. 2.1.2. The investigation techniques and modeling methodologies for the DEM, the thickness of the active layer and the sediment thickness are described in Sect. 2.2-2.4. All data presented in the present paper, as well as information on associated measurement techniques and the model in which the data are used, are listed in Table 1.

\subsection{Site description}

\subsubsection{General site description}

The TBL catchment (described in Johansson et al., 2015), is situated in close proximity to the Greenland Ice Sheet and approximately $30 \mathrm{~km}$ from the settlement of Kangerlussuaq, western Greenland (Fig. 1). The Kangerlussuaq region, reaching from the coast towards the ice sheet, contains an extensive ( $>150 \mathrm{~km}$ wide) ice-free area dominated by an undulating periglacial tundra environment with numerous lakes. The annual corrected precipitation $(P)$ recorded by the local automatic weather station in the TBL catchment, installed in April 2011, was $365 \mathrm{~mm}$ in 2012 and $269 \mathrm{~mm}$ in 2013 (Johansson et al., 2015). This is approximately twice as much as the precipitation measured in Kangerlussuaq for the corresponding periods (Cappelen, 2014). The mean annual air temperature (MAAT) at TBL is $-4.3^{\circ} \mathrm{C}$ for the same period (Johansson et al., 2015) and $-4.8^{\circ} \mathrm{C}$ in Kangerlussuaq (Cappelen, 2014).

The cold climate has resulted in a region of continuous permafrost. The permafrost is, in turn, interrupted by 


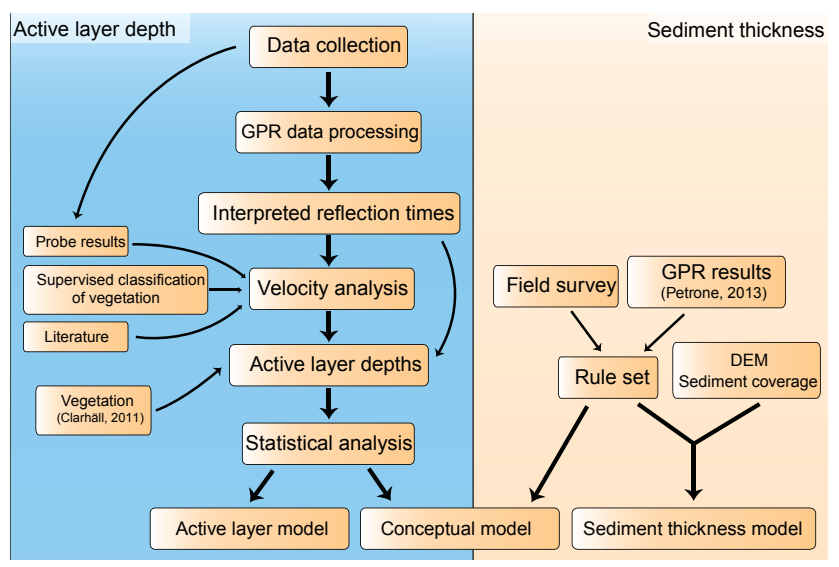

Figure 2. General work flow leading up to the completed models covering both active layer thickness and regolith thickness.

through taliks, i.e., local areas with no permafrost, often situated below larger lakes (Christiansen and Humlum, 2000). A bedrock borehole below TBL and the results from the investigations made in the instrumented drill hole have shown that the lake is underlain by a through-talik and that the permafrost in surrounding land areas reaches a depth of around 300 to $400 \mathrm{~m}$ (Harper et al., 2011). The active layer freezes and thaws in cycles directly related to the seasonal variations in air temperature, with a maximum thawed depth at the end of summer.

The area of TBL is $0.37 \mathrm{~km}^{2}$ and its catchment covers an area of $1.56 \mathrm{~km}^{2}$ (Johansson et al., 2015). There is a height difference of around $200 \mathrm{~m}$ from the deepest part of the lake ( $\sim 30 \mathrm{~m}$ water depth) to the highest point in the southwestern part of the catchment (Fig. 3).

Most of the catchment has sparse but continuous vegetation cover, with some exceptions of areas with exposed bedrock or till. Vegetation is in general dominated by dwarfshrub heath. There are no trees, and the shrubs rarely exceed $0.5 \mathrm{~m}$ in height. There is a fairly limited number of vascular plant species, but the spatial distribution and density of individual species are highly variable in different parts of the catchment. The vegetation has been classified into several categories (Fig. 3a), based on field surveys and classification in aerial photographs (Clarhäll, 2011). Heath covers a large portion of the catchment; major plants in this class are $B e$ tula nana, Salix glauca and Vaccinium uliginosum. The vegetation is classified as either Betula or Salix if any one plant dominates the coverage. In general, the class heath consists of a mixture of plant species where dwarf shrubs are a significant constituent. Barren surfaces (Fig. 3a), completely lacking vegetation, are present in exposed areas where wind has eroded the silt layer and exposed underlying till or bedrock. Grasslands on ridges and exposed dry areas (Fig. 3a) are also scattered around the catchment. The catchment in general constitutes a very dry environment, but a few topographically low areas can be saturated with water during and after events of high precipitation, as well as when the snowpack melts during springtime. Areas with relatively high soil water content have thus developed and are here termed wetlands.

\subsubsection{Quaternary geology of the study area}

The geographical distribution of sediment types was determined during field surveys in the summers of 2010 and 2011. Sediment samples were taken from seven locations (Fig. 3b) and analyzed for grain-size distribution. Results from the field observations were used to construct a conceptual model illustrating the stratigraphical distribution of the most commonly occurring sediment types. The results are partly reported by Clarhäll (2011).

The Quaternary geology within the catchment was first described by Clarhäll (2011). An updated sediment map, based on new results from later excavations and field observations, is presented in the present paper (Fig. 3b). The uppermost sediments are dominated by eolian silt, underlain by till, which is also representative of the regional area (Clarhäll, 2011). Deposition of the eolian silt has occurred since at least ca. 4750 years BP (Willemse et al., 2003), when the ice margin was situated further inland (van Tatenhove et al., 1996). Surficial glacial till and bedrock outcrops can be found in places where erosion has removed the eolian silt. The boundary is often sharp with a scarred surface revealing the underlying till. The till is loosely compacted and is dominated by sand and gravel with a low content of silt and clay, which indicates a marginal deposition in front of the ice sheet (Clarhäll, 2011). Glaciofluvial deposits are also found in several areas, mainly in the northern regions of the catchment. Stratigraphical studies have shown that the till contains layers of water laid deposits and the hydrological properties of the till and the glaciofluvial deposits can therefore be regarded as comparable. In the central and low-lying parts of the major valleys, silt deposition and accumulation of organic material have resulted in areas of peaty silt. The floor of the lake is covered to a large extent by currently accumulating silt. Permafrost-related processes have also led to the development of ice-wedge polygons in local areas where the sediments are characterized by a relatively high water content.

\subsection{Digital elevation model}

A first digital elevation model (DEM) for TBL and its catchment was constructed in 2011 (Clarhäll, 2011). In 2012, a lidar survey and a bathymetric survey of the TBL catchment area were carried out. A new improved DEM, with the same extent as the previous one, was constructed within the present study from the newly acquired data. 

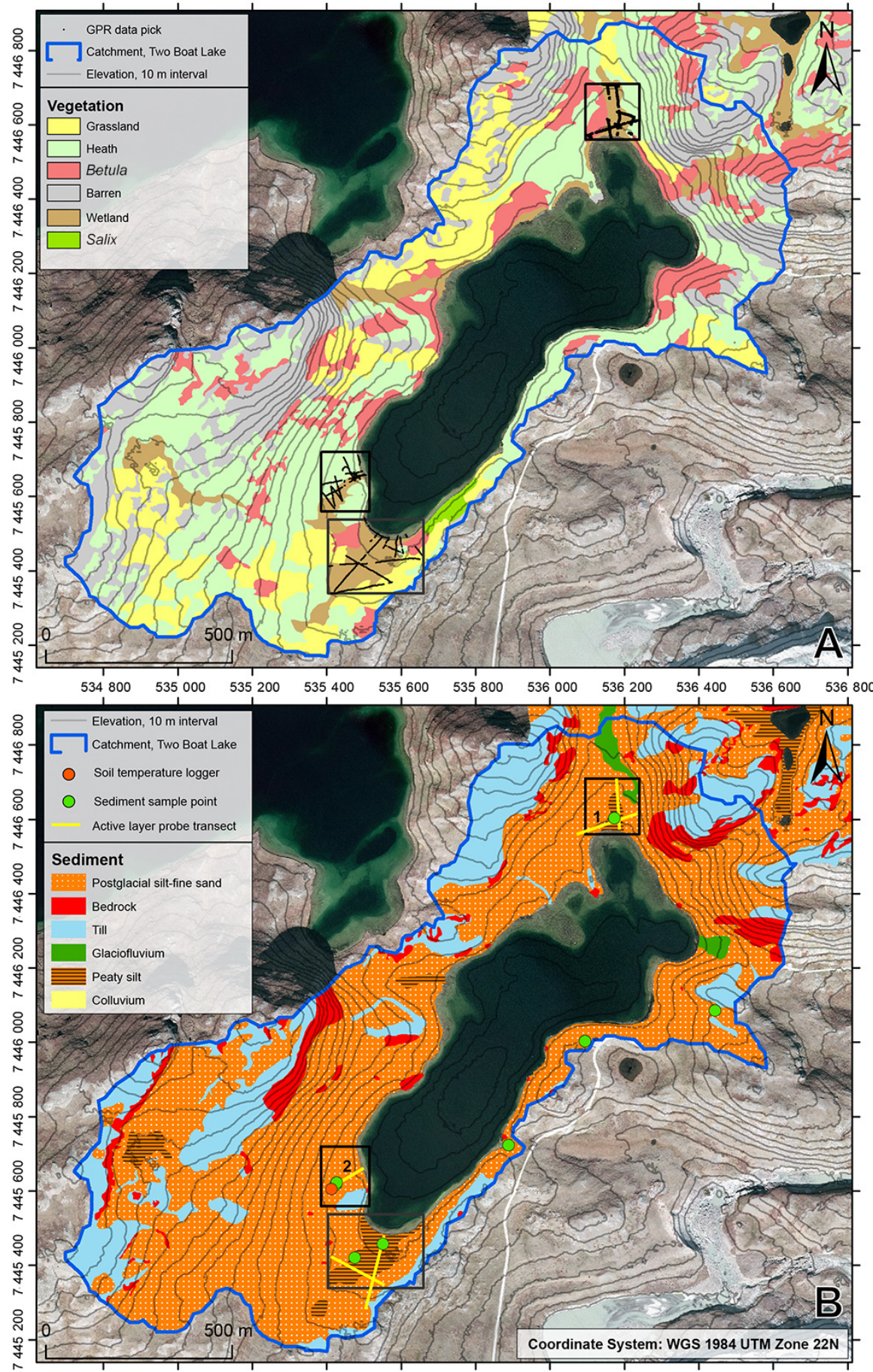

Figure 3. (a) Vegetation map of the catchment outlined in black with defined sub-areas and selected GPR data points. (b) The aerial distribution of sediment classes and bedrock outcrops within the catchment in addition to field measurements. Spatial distributions are from Clarhäll (2011).

The lidar data were collected for a large part of the TBL catchment using a Riegl Z-450 (2000 m range) laser scanner. Survey stations and ground control points were surveyed and georeferenced to geodetic control quality $(\sim$ centimeter precision) using a Leica 1200 GPS receiver processed by Le- ica Geo Office and corrected to a local GNSS (global navigation satellite system) base station located with a baseline distance of less than $5 \mathrm{~km}$. The lidar data were projected to UTM 22N, adjusted to a local GR96 (Greenland Reference System 1996) datum point in Kangerlussuaq and converted 
from WGS84 ellipsoid heights to the local elevation datum. The vertical offset between the ellipsoid height and the local datum is $-31.1 \mathrm{~m}$.

Approximately 21 million elevation values were collected during the lidar data measurement. These values were recalculated to mean values within $1 \mathrm{~m}$ cells. In the terrestrial areas not covered by lidar data, elevation data from the previous DEM (Clarhäll, 2011) were used. Lidar data within $2 \mathrm{~m}$ from the lake shoreline were removed to obtain a smoother transition between the lake and the terrestrial area in the DEM.

The bathymetric survey of TBL was made with a combined echo sounder and GPS (Humminbird 798ci HD SI) attached to a boat. Positions, water depth and bottom hardness were stored every second during the measurements. Incorrect measurements were subsequently removed and in some areas depth data were thinned out to obtain a similar data density over the surveyed area. After these corrections, approximately 18500 measurements remained. Monitoring of lake level variations was initiated in September 2010 (Johansson et al., 2015). All water depth values from TBL were adjusted to the lake level at the beginning of the monitoring and were converted to the coordinate system used for the lidar data. Points were added along the lake shoreline every $5 \mathrm{~m}$ using the extension of the lake shown in Clarhäll (2011). The lake shoreline was adjusted to the lidar data and a lake level of $336.4 \mathrm{~m}$ a.s.l. was determined. The depth data from TBL were recalculated from the lake level, i.e., from depth in meters below $336.4 \mathrm{~m}$ a.s.l.

Finally, terrestrial data and depth values were merged to a data set of approximately 1.3 million points. From this data set, a $5 \mathrm{~m}$ by $5 \mathrm{~m}$ resolution DEM was constructed. The interpolation of point values was done using the Geostatistical Analysis extension in ArcGIS 10.1. Ordinary Kriging was chosen as the interpolation method (Davis, 1986; Isaaks and Srivastava, 1989). The different data sources and their estimated accuracy are shown in Appendix A. The resulting DEM is available at PANGAEA (doi:10.1594/PANGAEA.845258).

\subsection{Thickness surveys of sediments and active layer}

The total sediment thickness in the catchment was investigated by GPR in April 2011 (Petrone, 2013). A MALÅ X3M shielded antenna GPR system, with a central frequency of $250 \mathrm{MHz}$, was used. A Trimble R7 GPS was connected to the GPR to log the position of each measurement. Each profile was measured by dragging the GPR equipment at constant walking speed. The measurements were carried out in straight profiles perpendicular to each other to analyze the spatial variation in sediment thickness. The methodology is thoroughly described in Petrone (2013).

To establish absolute sediment depth values, the start and end points of each transect were situated at or nearby bedrock outcrops. This allowed the bedrock reflector to be easily identified and continuously traced along the transects. The relationship between sediment thickness and topography (DEM) constitute the basis for the sediment model. The updated DEM, described in Sect. 2.3, was used to extract the steepness of the topography. The surface sediment map (Fig. 3b) was also used as input to provide the spatial distribution of sediment types.

The thickness of the active layer was investigated by probing in 83 points in several transects in August 2011 using a steel rod (Fig. 3b). All points were located in transects at semi-regular intervals covering different soil types, vegetation and topographic properties (such as elevation, slope and aspect). The relevant transects are marked with "1" and "2" in Fig. 3b. An additional GPR survey was carried out simultaneously to the probe measurements, using GPR equipment identical to that used during the earlier measurements. This survey was concentrated to three sub-areas (Fig. 3a). All GPR profiles related to the active layer surveys were processed and analyzed in the same way as in Petrone (2013). Low- and high-frequency noise was reduced by applying dewow and bandpass filters and each profile was geo-referenced. A clear reflector, identified as the reflection of the boundary between thawed and frozen sediments, can be identified in most profiles. In profiles with a less clear and/or discontinuous reflector, or in cases of extremely noisy radargrams, the data were discarded. All remaining selected points, representing the interpreted travel time from the surface to the permafrost boundary and back, are seen in Fig. 3a.

\subsection{Modeling of active layer depth and sediment thickness}

\subsubsection{Vegetation class and radar wave velocity correlation}

As previously mentioned, recent studies involving GPR and the active layer have shown that there is a strong influence on water content, and thus electromagnetic wave velocity, from different vegetation types (Gacitúa et al., 2012). A similar approach is used in the present study. In order to calculate the depth of the active layer it is necessary to know the wave velocity in the medium. Eolian silt covers a major part of the catchment, and it is considered homogeneous down to the underlying till. Thus, mainly water content and organic matter varies in the sediment layer, hosting the active layer. The variation in vegetation within the study area can therefore be correlated to soil water content (and hence wave velocity in the eolian silt). Probe transect 1 , marked in Fig. 3b, is situated in the northern valley of the catchment. The results and interpretation from the transect are shown in Fig. $4 \mathrm{a}-\mathrm{c}$ and the profile is presented in $\mathrm{E}-\mathrm{W}$ direction. Processed GPR data are displayed in Fig. 4a, showing travel time and reflectors. The identified permafrost table reflector and active layer depths from probing are presented in Fig. 4b. Electromagnetic wave velocity was calculated for the probed 

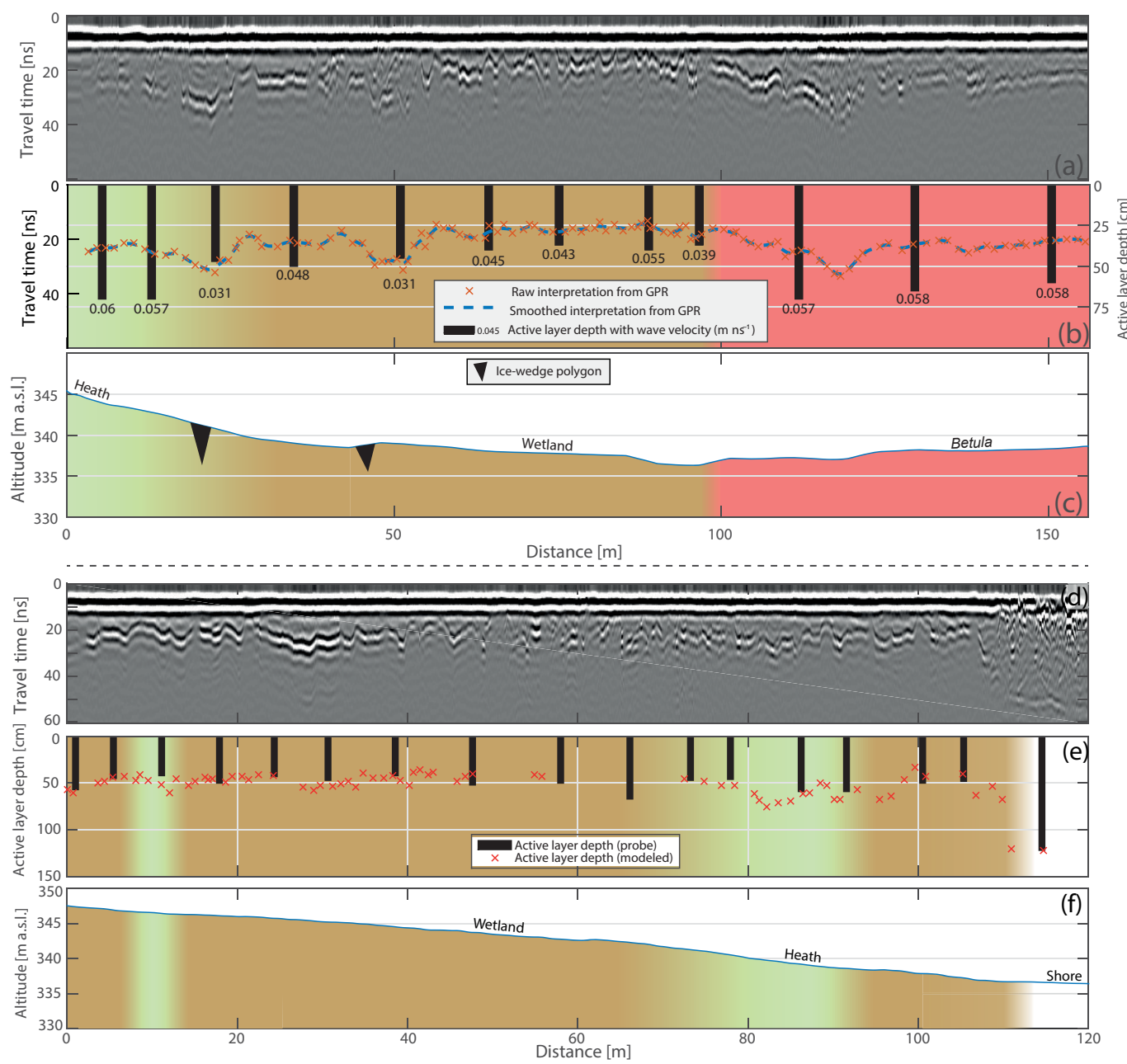

Figure 4. Profile 1 (Fig. 3b) with (a) the raw data from the GPR, (b) probe depths to permafrost and selected permafrost reflectors from the raw data. Values below probe bars represent the calculated electromagnetic wave velocity at the probe locations and surface vegetation classes as background. (c) Elevation, permafrost features and vegetation. Profile 2 (Fig. 3b) with (d) raw data from the GPR, (e) probe depth to permafrost with modeled depth from raw data and Table 2 as well as vegetation classes in the background. (f) Surface altitude and vegetation along profile.

locations. The corresponding surface altitude and vegetation class variation is shown in Fig. 4c, along with any permafrost features. For clarity, the vegetation classes along the transect shown in Fig. 4c are also included in panel b. Mean values of radar wave velocity were assigned to corresponding vegetation classes (heath: $0.059 \mathrm{~m} \mathrm{~ns}^{-1}$; wetland: $0.045 \mathrm{~m} \mathrm{~ns}^{-1}$; Betula: $0.058 \mathrm{~m} \mathrm{~ns}^{-1}$ ). Grassland, absent along transect 1 , was assigned a velocity value based on heath and Betula $\left(0.0585 \mathrm{~m} \mathrm{~ns}^{-1}\right)$, assumed to be similar in soil water content. The wave velocity near the shore line (water class) was assigned a velocity of $0.05 \mathrm{~m} \mathrm{~ns}^{-1}$ based on saturated silt (Neal, 2004). Assigned velocities and the source for the estimation are presented in Table 2.

\subsubsection{Upscaling of active layer depth to catchment scale based on vegetation classes}

The vegetation map presented in Clarhäll (2011), shown in Fig. 3a, was based on areal photographs of the catchment. However, the classification was not of satisfactory detail for the analysis in the present study since it had to better match the high resolution of the GPR measurements. In order to increase the spatial resolution of the vegetation map, the same aerial photographs were used to define vegetation classes within the areas investigated by GPR and probe measurements (Fig. 3a). To this end, a so-called supervised classification on pixel basis was performed using ArcGIS. Based on pre-defined areas, with assigned classes (training areas), the software analyzes and matches groups of pixels and assigns every pixel to the predefined classes. The same vegetation classes were used for both the high- and low-resolution veg- 
Table 2. Summary of the results from the velocity analysis in Fig. 4.

\begin{tabular}{lrl}
\hline Vegetation class & $\begin{array}{r}\text { Electromagnetic wave } \\
\text { velocity }\left(\mathrm{m} \mathrm{ns}^{-1}\right)\end{array}$ & Source \\
\hline Wetland & 0.045 & Fig. 4b \\
Betula & 0.058 & Fig. 4b \\
Heath & 0.059 & Fig. 4b \\
Grassland & 0.0585 & Fig. 4b \\
Shore/water & 0.05 & Neal (2004) \\
\hline
\end{tabular}

etation maps. The resulting maps provided high-resolution information on vegetation cover over the areas investigated by the GPR and probe measurements.

All reflectors (Fig. 3a), i.e., points within the area with a known travel time for the electromagnetic wave to the permafrost table, were assigned a wave velocity based on Table 2 and the vegetation in that point. The velocity estimations for each vegetation group, presented in Table 2, were controlled by applying the velocities for each vegetation group to another transect, transect 2 in Fig. 3b. The processed GPR data, plotted topography and vegetation, as well as the permafrost boundary and probe measurements of transect 2, are shown in Fig. 4d-f. The comparison between measured and modeled values of the active layer thickness (Fig. 4e) shows good accuracy $\left(R^{2}=0.84\right)$ when using the estimated velocities in Table 2. In summary, Fig. $4 \mathrm{~b}$ presents active layer depths along transect 1 based on probe measurements, whereas Fig. 4e presents active layer depths along transect 2 based on calculated velocities for each vegetation group along this transect.

To calculate the active layer thickness for all reflector points in Fig. 3, the re-classified vegetation maps described above were used. Each GPR measurement was assigned the estimated velocity from Table 2, corresponding to the vegetation class. The results are summarized in Table 3, listing the different vegetation classes and the calculated active layer depths. The mean active layer thickness for each vegetation class was used to construct the catchment model of the active layer. Since no measurements of active layer thickness were made over bedrock, the value of $2.0 \mathrm{~m}$ for the depth corresponding to the barren class has been taken from Harper et al. (2011), which is based on bedrock borehole temperatures in the area. The mean active layer thickness values of each vegetation class were fed into the lower-resolution map of the vegetation coverage, resulting in the catchment-wide model of the variation in active layer thickness. Sharp boundaries between vegetation classes (and thus active layer depth) were smoothed using a mean filter.

Data from a soil temperature station (Fig. 3b), continuously monitoring temperatures every $3 \mathrm{~h}$ in the sediments at $0.25,0.5,0.75 .1 .0,1.5$ and $2.0 \mathrm{~m}$ depth below surface, were used as an additional source of information regarding the active layer depth (Johansson et al., 2015). The station is lo- cated in heath vegetation along transect 2 (Fig. 3b). The data have been used partly to verify the result of the active layer model, as supportive information regarding the seasonal evolution of the active layer within the catchment, and to analyze annual differences in the thaw depth of the layer.

\section{Results}

\subsection{Sediment thickness}

The final result is a 3-D model illustrating the thickness of the most commonly occurring sediment types. Based on hydrological properties, the sediments have been divided into three major classes: glacial deposits, eolian silt and lacustrine silt. The classes are further described below.

Glacial deposits. This class includes both till and glaciofluvial deposits, since these deposits have similar hydrological properties (see above). The GPR measurements show that the thickness of the glacial deposits ranges from $0 \mathrm{~m}$ where bedrock is exposed to $10 \mathrm{~m}$ in the central and lowlying parts of the valleys and the lake floor (Petrone, 2013). The slope of the ground surface has been assumed to mainly dictate the thickness of this layer. Based on results from the GPR measurements (Petrone, 2013) and the sediment map, larger flat zones (slope $<5^{\circ}$ ) has been assigned a thickness of $10 \mathrm{~m}$, while steeper (slope $>60^{\circ}$ ) sections lack any glacial deposits. A linear interpolation was used to assign the thickness value between the minimum and maximum values. In addition, the modeled sediment thickness was manually increased where the glacial deposits comprise positive morphological landforms, such as along ridges.

Eolian silt. This sediment class covers a major part of the catchment and is superimposed on the glacial deposits. In steep topography, no silt has accumulated or has been eroded and re-deposited elsewhere. In several flat and exposed areas, wind has eroded and removed any vegetation and silt, revealing the surrounding silt and underlying till. The thickness of the silt in these regions is approximately $0.2 \mathrm{~m}$. The maximum depth of the silt is found in the central and lowlying parts of the valleys, reaching a thickness of $1 \mathrm{~m}$. Thus, the thickness of the eolian silt is also largely dependent on the topography, as well as the distance from any eroded sections. From the field observations and coverage maps, eolian silt has been assigned a thickness of $0.2 \mathrm{~m}$ in proximity to eroded sections and steeper parts (slope $>50^{\circ}$ ) to $1.0 \mathrm{~m}$ in the flat (slope $<5^{\circ}$ ) and low-lying sections of the catchment (Clarhäll, 2011).

Lacustrine silt. These sediments are superimposed on the glacial deposits at the lake floor. Due to wave action, no deposits of lacustrine silt are found in the shallow $(<2 \mathrm{~m})$ parts of the lake. In the deeper parts, the deposits have a thickness of around $1.5 \mathrm{~m}$ (Petrone, 2013). The thickness of the lacustrine silt deposit between the shallow and the deeper part is based on linear interpolation. 
Table 3. Summary of GPR points from Fig. 3a and wave velocities from Table 2.

\begin{tabular}{lrrr}
\hline Vegetation class & Number of points & Active layer mean depth (m) & Standard deviation $(\mathrm{m})$ \\
\hline Wetland & 748 & 0.48 & 0.09 \\
Betula & 57 & 0.7 & 0.13 \\
Heath & 288 & 0.68 & 0.09 \\
Grassland & 42 & 0.81 & 0.05 \\
Shore/water & 99 & 1.27 & 0.16 \\
Barren (bedrock) & - & 2 & - \\
\hline
\end{tabular}

* Value from Harper et al. (2011), based on temperature measurements in boreholes.

Figure 5 shows the final model of the thickness of each sediment layer. Glacial deposits (Fig. 5a), mainly till, have been deposited on top of the bedrock during periods with a more extensive Greenland Ice Sheet. At higher elevations, and where the slope is steep, no glacial deposits are generated in the model. Thinner layers of sediment are found in close proximity to exposed bedrock. In flatter terrain and in central parts of valleys, the sediment thickness increases to around $10 \mathrm{~m}$. A thin layer of eolian silt covers much of the glacial deposits (Fig. 5b). These eolian deposits have a maximum depth of $1 \mathrm{~m}$ in flat terrain and generally decrease where the topography steepens. Figure 5b also shows the lacustrine silt at the lake floor. Lake deposits are only found at depths below $2 \mathrm{~m}$ in the model, and they gradually increase with depth, reaching a maximum of $1.5 \mathrm{~m}$ at the deepest part of the lake.

The results have been used to construct a schematic sediment distribution model within the catchment (Fig. 6). Till makes up the majority of the volume of sediment and is present in all areas of the catchment. At the valley floors, the eolian silt is partly rich in organic material due to higher soil water content and is denoted peaty silt. The maximum thickness of the sediments can be found where the glacial deposits constitute positive landforms, such as along glaciofluvial ridges.

\subsection{Active layer}

Based on the methodology described in Sect. 3.2 and 3.3, a catchment-wide model of the active layer was produced (Fig. 7a). The shallowest active layer is found within the valley wetlands, often in close proximity to the lake and has an average maximum thickness of $0.48 \mathrm{~m}$. Areas dominated by heath, Betula and grassland, generally constituting drier areas, have a thicker maximum active layer (between 0.68 and $0.80 \mathrm{~m}$ ). The thickest active layer is, however, found in the barren areas with exposed bedrock $(2.0 \mathrm{~m})$, where the predefined value of $2.0 \mathrm{~m}$ is used (see above). The active layer depth gradually increases along the shore, where it evolves into the talik feature. The schematic figure represents a general valley area of the catchment, ranging from the catchment boundary towards the lake. There are four main valleys in the catchment area, which are marked with black dashed lines in
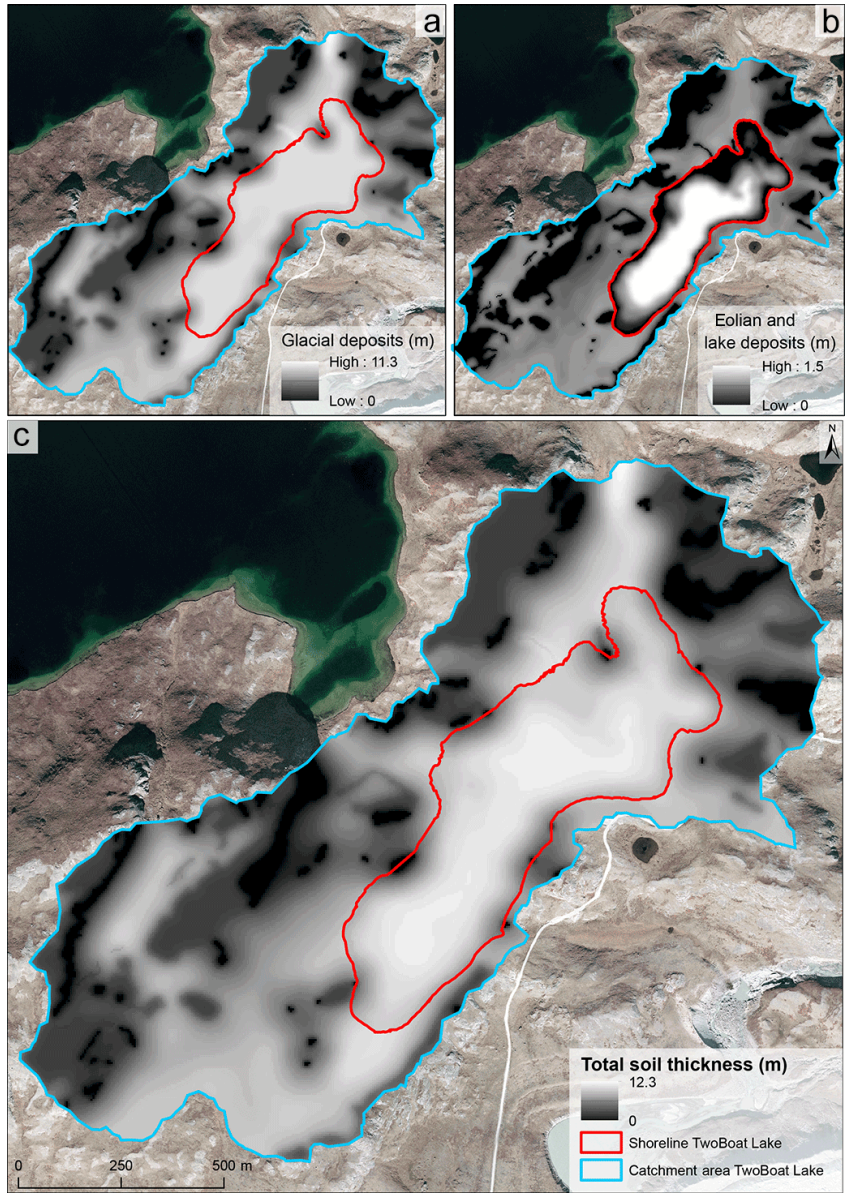

Figure 5. Modeled sediment thickness for different classes of sediments in the catchment of Two Boat Lake. (a) Glacial deposit (till and glaciofluvial material) thickness, (b) eolian and lake deposits, and (c) total sediment thickness including superimposed glacial, eolian and lake deposits.

Fig. 7a. The results and the correlation between active layer depth and vegetation are schematically visualized in Fig. 7b. Polygonal surfaces and ponds where water is residing for longer periods of time have not been incorporated into the catchment-wide model. Probe measurements in the field have shown that these have a relatively thin active layer (approxi- 


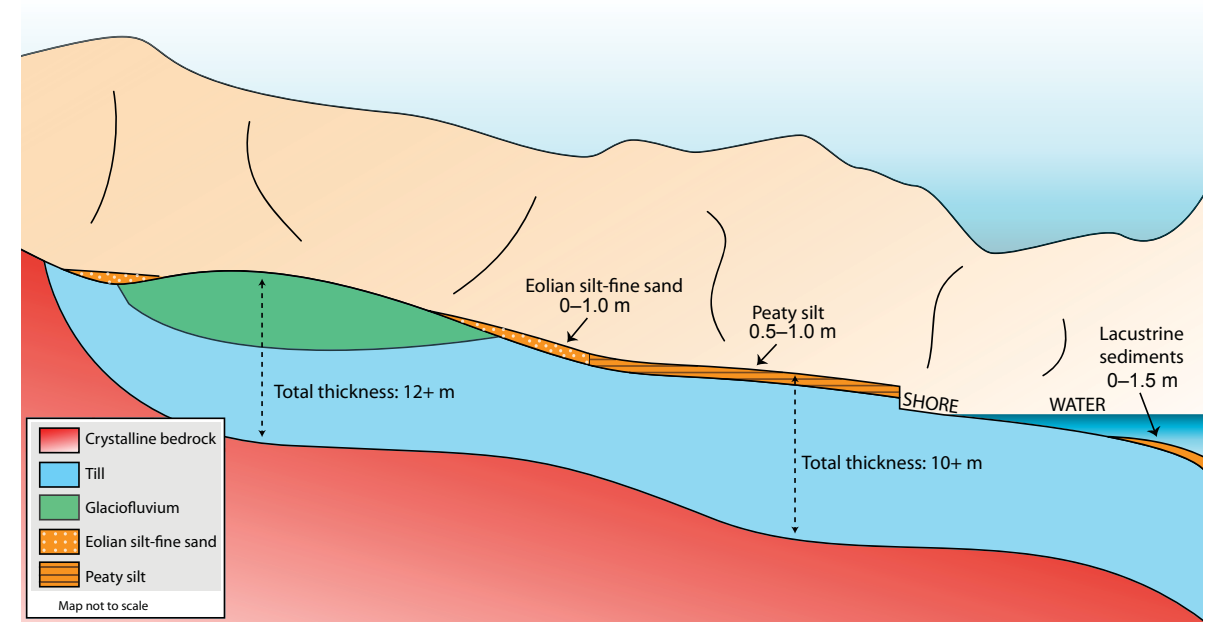

Figure 6. Schematic model and presentation of the sediment thickness from the lake (right) towards higher elevations (left) in a cross section through the valley. Sediment classes and its visual assignment are based on Fig. $3 \mathrm{~b}$.

mately $0.3 \mathrm{~m}$ ) and have thus been included in the schematic model (Fig. 7b).

Based on the soil temperatures, monitored in the vegetation class heath, the development of the thaw depth in the active layer can be visualized in a contour plot which covers the entire period of September 2010 to December 2015 (Fig. 8). The maximum observed thaw depth in 2011 (Fig. 8), when the GPR measurements were carried out, is $0.75 \mathrm{~m}$, which is within the range of the active layer depth for the vegetation class heat calculated to $0.68 \pm 0.09 \mathrm{~m}$ (Table 3). When looking at the maximum thaw depth each year, 2011 stands out as a colder period. In subsequent years the thaw depth reaches $0.8 \mathrm{~m}$ or more. A consistent thaw depth, deeper than $25 \mathrm{~cm}$, is reached in June in all years. The plot does not show shallow $(<25 \mathrm{~cm})$ temperature fluctuations but temperatures in the uppermost sediments rise above $0{ }^{\circ} \mathrm{C}$ in late April to early May (Johansson et al., 2015). In June, the air temperature is always above freezing and the thawed depth gradually migrates downward in the soil. Maximum temperatures in the upper part of the soil occur in early August, whereas the thawed layer continues to increase in thickness until early September, although the rate slows down during August. The upper part of the active layer freezes once air temperatures drop below $0{ }^{\circ} \mathrm{C}$ for longer periods. Large fluctuations in temperatures during the October months led to periods with freezing and thawing of the upper part of the active layer at the same time as the lower boundary of the active layer migrates upwards. Data from the soil temperature station show that parts of the sediments stay thawed until mid-October, and in warmer years, such as 2012, as far as into early November. In this way, different surface conditions leads to variation in not only the length of the active period, i.e., the time period when a thawed active layer exists, but also the active layer thickness. The general pattern of the evolution of the active layer is similar each year: a rapid thaw in early June which stagnates in late August followed by a more complex refreeze in late September to October.

\section{Discussion}

GPR is a powerful tool that can be used to investigate several properties of the subsurface. During frozen ground conditions it can be used to determine the depth to the bedrock and any intermediate stratigraphical horizons. In areas with relatively homogeneous sediments and a known Quaternary history, such as the present study area, the measurements can be combined with a digital elevation model and field observations to construct a model of the different sediments types and their spatial variation in thickness. In this study we rely on radar profiles which transect bedrock outcrops and make it possible to trace the bedrock and thus sediment thickness. Since we use the pronounced topography in the catchment to such a large extent when modeling the sediment thickness, it might not be feasible to use the same methods in areas with less pronounced topography. GPR is also a suitable method to investigate the permafrost table in periglacial environments, due to the large difference in electrical properties between thawed and frozen sediments. Since soil water content influences the permittivity of the medium to a large degree, one must first estimate the permittivity of the material. Here we used aerial photographs to tie vegetation classes to a specific soil water content (and hence its dielectric properties), using probe measurements to determine the absolute depth to the permafrost table. This allowed us to process the GPR measurements and resulted in over a thousand points for the active layer thickness over several vegetation classes. As can be seen in Fig. 4b and Table 3, the active layer thickness can vary significantly within small areas and within vegetation classes. It would be very time-consuming to perform the probe measurements with a resolution as high as that which 

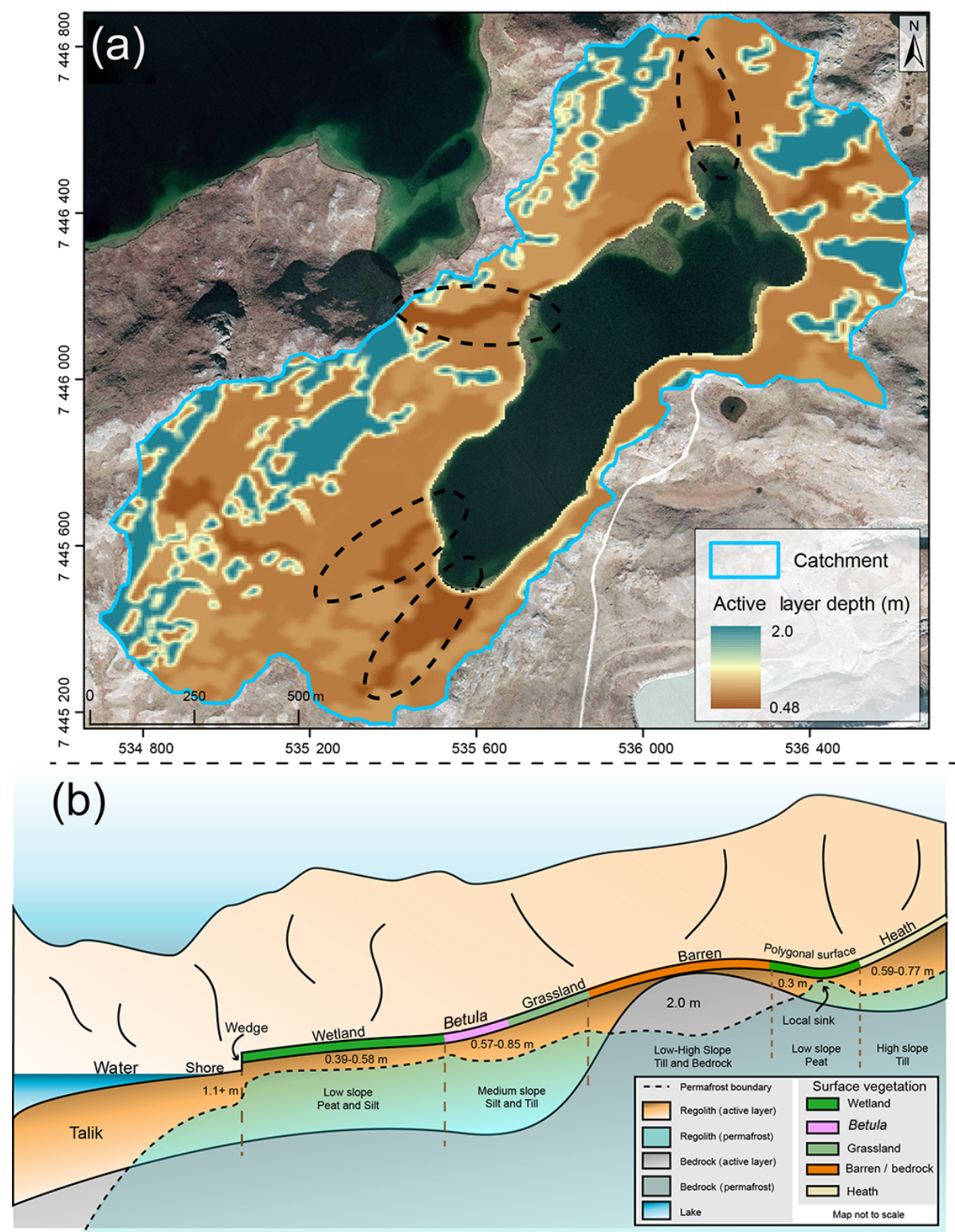

Figure 7. (a) Maximum active layer thickness over the entire catchment of Two Boat Lake with dashed ellipsoids marking valleys found within the catchment. (b) Schematic model of the variation in active layer thickness in a cross section of a valley found within the catchment of Two Boat Lake and its relation to topography, regolith, permafrost features and surface vegetation.

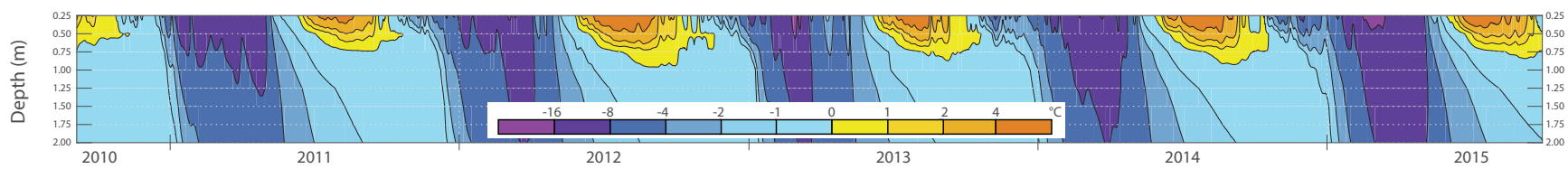

Figure 8. Temperature in the upper $2 \mathrm{~m}$ of sediments during the period of September 2010 to December 2015. Contour values are shown in ${ }^{\circ} \mathrm{C}$, where yellow to orange gradients represent the active layer and blue gradients frozen soil.

was used with the GPR, especially when working in a large area such as the studied catchment. However, radar measurements can continuously map variations in active layer thickness in a relatively short amount of time. The result from the GPR showed distinct variations in thickness of the active layer between vegetation classes. The variation between classes was used to upscale the results to a catchment-wide model. An uncertain factor is the active layer thickness in 
barren areas, often with little to no soil water content. Here we used temperature measurements from a nearby borehole, which showed the active layer extending down to $2.0 \mathrm{~m}$ in the bedrock (Harper et al., 2011). The significant increase in active layer thickness in the bedrock compared to sediments can be explained by the difference in thermal properties, namely thermal diffusivity. Bedrock has a higher diffusivity compared to the sediments and transfer heat at a higher rate (Janza, 1975), affecting the energy transfer from the surface and leading to deeper penetration of energy (heat) in a given active period. The same argument can be applied to the difference in the active layer thickness between different vegetation classes. Since the surface vegetation is directly connected to soil moisture content, differences in water content of the sediments will affect the diffusivity of the material. The diffusivity of water $\left(1.5 \times 10^{-3} \mathrm{~cm}^{2} \mathrm{~s}^{-1}\right)$ compared to that of soil $\left(3-5 \times 10^{-3} \mathrm{~cm}^{2} \mathrm{~s}^{-1}\right)$ will lead to a quicker thickening of the active layer and hence deeper permafrost table during the active period. The energy from the surface has several sources, including air temperature, precipitation and solar radiation, that will also influence the active layer thickness. This relationship has not been investigated in the present study and variations in these parameters within the catchment are not accounted for in detail. However, investigations of the active layer depth have been carried out in different areas within the catchment, and local variations are therefore assumed to be included in the final model results. In this study we focus on the spatial and temporal variation in the active layer within the catchment. The permafrost boundary is at, or very near, its deepest point in August. However, it should be noted that the GPR measurements were carried out in 2011. This year is shown to have the shallowest observed thaw depth at the soil temperature station in the end of the active period. During the period of soil temperature measurements (Fig. 8), the temperature sensor at $1 \mathrm{~m}$ depth never experienced temperatures below $0{ }^{\circ} \mathrm{C}$. The average thaw depth in the active layer for the period $2011-2015$ is $0.9 \mathrm{~m}$. The measurements and active layer model produced here reflect the year of 2011 and should therefore perhaps be seen as a low value for the thickness of the active layer.

Long-term variations in the thawing depth or in the duration of the active period may affect the local hydrology and transport of matter in the catchment. An increased thaw depth of the active layer might open up new pathways for water to flow, drastically altering the subsurface hydrology of the catchment. Additionally, it is unclear whether increased thawing of the active layer will lead to drier or wetter conditions in Arctic landscapes, which affects the cycling of carbon. The presented models of ALT and sediment thickness can be used as input in hydrological models aiming at investigating the storage and partitioning of water in Arctic landscapes under increased thawing conditions.

\section{Data availability}

All data needed to construct the soil and active layer models, as well as the models themselves, are freely available from PANGAEA: doi:10.1594/PANGAEA.845258. The spatial information on sediment distribution with depth is valuable when assigning hydraulic properties to conceptual and numerical hydrological models of the catchment, which in turn may be used to model biogeochemical transport and processes in both the limnic and terrestrial system.

\section{Conclusion}

We have used a combination of remote sensing, groundpenetrating radar, field surveys, digital elevation model analysis and probe measurements to construct two models over the catchment: one of the sediment thickness and another of the maximum active layer thickness. The sediment thickness ranges from $0 \mathrm{~m}$ in bedrock outcrops areas to more than $12 \mathrm{~m}$ in the central valleys. The active layer is mostly confined within the upper $0.7 \mathrm{~m}$ of the sediment (excluding the bedrock), which mostly consists of eolian silt. The active layer thickness varies from $0.3 \mathrm{~m}$ in the wetland areas to $2 \mathrm{~m}$ in areas with bedrock outcrops.

We show that, by using relatively simple methods, it is possible to upscale local point measurements to catchmentscale models in areas where the upper subsurface is relatively homogeneous. By identifying generalized active layer thickness values for different vegetation classes, we were able to construct a 3-D model of the active layer thickness at catchment scale based on vegetation coverage. 
Appendix A: Data sources to the digital elevation model (DEM)

The digital elevation model was developed using data from three data sources:

i. an aerial photo from the company providing aerial photos, Scancort;

ii. combined GPS and echo-sounding measurements in the lake to create the bathymetry;

iii. lidar data from measurements presented in the present paper.

The coverage for each data source is presented in Fig. A1.

Details about the data processing based on information from Scancort are presented in Clarhäll (2011). Two measurement campaigns with the combined GPS-echo-sounding technique were performed: one campaign in 2010 and one in 2011. Details about the measurements performed in 2010 are presented in Clarhäll (2011), and the measurements performed in 2011 are described in the present paper. The GPS acquisition for the bathymetry was done without real-time kinematic correction, as there is no such option for this particular GPS receiver. The combined GPS-echo-sounding equipment (Humminbird 798ci HD SI) has estimated accuracy in the range of $\pm 1 \mathrm{~m}$ in the horizontal plane and $\pm 0.1 \mathrm{~m}$ in depth.

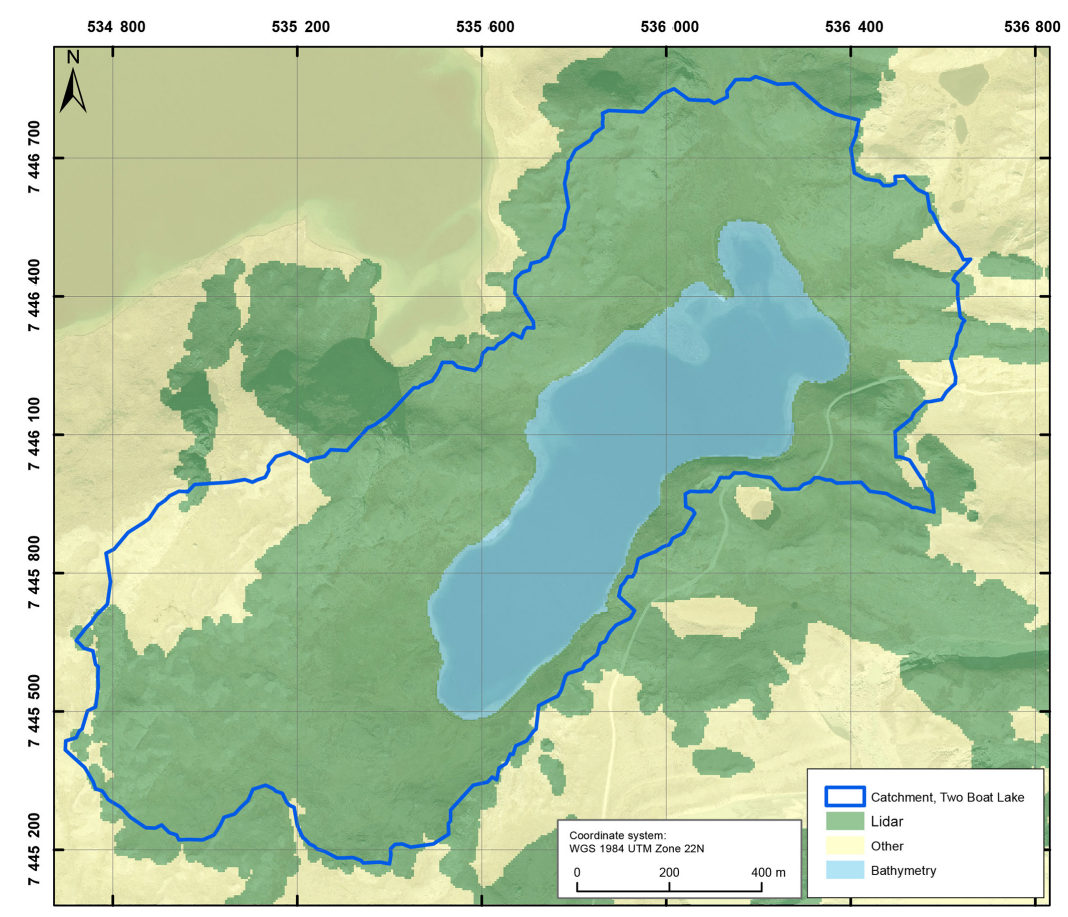

Figure A1. The different data sources used when constructing the digital elevation model of the TBL catchment. 
Author contributions. Johannes Petrone prepared the manuscript with contributions from all co-authors, performed the GPR measurements and the analysis of all GPR data, and established the method for upscaling the GPR data to represent the active layer thickness at catchment scale by combining them with vegetation data.

Gustav Sohlenius carried out the site investigation related to sediment thickness and properties, was involved in the modeling of the sediment thickness, and wrote the associated parts of the manuscript.

Emma Johansson (hydrology and meteorology) and Tobias Lindborg (ecology and chemistry) are responsible for the GRASP field program. They were both involved in the planning of all field investigations presented in this paper and were actively involved in the writing of this paper.

Mårten Strömgren wrote the parts describing the construction of the digital elevation model and was involved in the associated investigations.

Lars Brydsten was involved in the investigations associated with the digital elevation model.

Jens-Ove Näslund was involved in the field work and was actively involved in the writing of the paper.

Acknowledgements. The majority of the work was conducted as a part of the Greenland Analogue Surface Project (GRASP) funded by the Swedish Nuclear Fuel and Waste Management Company (SKB). The authors would like to thank the Greenland Analogue Project (GAP) for providing additional lidar data of the catchment, and Kangerlussuaq International Science Support (KISS) for providing logistical support throughout the years.

Edited by: G. G. R. Iovine

Reviewed by: J. Engström, O. G. Terranova, and one anonymous referee

\section{References}

Burrows, M. T., Schoeman, D. S., Buckley, L. B., Moore, P., Poloczanska, E. S., Brander, K. M., Brown, C., Bruno, J. F., Duarte, C. M., Halpern, B. S., Holding, J., Kappel, C. V., Kiessling, W., O’Connor, M. I., Pandolfi, J. M., Parmesan, C., Schwing, F. B., Sydeman, W. J., and Richardson, A. J.: The pace of shifting climate in marine and terrestrial ecosystems, Science, 334, 652-655, doi:10.1126/science.1210288, 2011.

Cappelen, J. (Ed.): Weather and climate data from Greenland 19582013 - Observation data with description, DMI Technical Report 14-08, Copenhagen, 2014.

Christiansen, H. and Humlum, O.: Permafrost, in: Topografisk Atlas Grönland, edited by: Jakobsen, B. H., Böcher, J., Nielsen, N., Guttesen, R., Humlum, and O., Jensen, E., Det Kongelige Danske Geografiske Selskab/Kort \& Matrikelstyrelsen, 32-35, 2000.

Clarhäll, A.: SKB studies of the periglacial environment - report from field studies in Kangerlussuaq, Greenland 2008 and 2010, SKB P-11-05, Swedish Nuclear Fuel and Waste Management Co., 2011.

Davis, J. C.: Statistics and Data Analysis in Geology, John Wiley and Sons: New York, 1986.
Doolitle, J. A., Hardisky, M. A., and Gross, M. F.: A groundpenetrating radar study of the active layer thickness in areas of moist sedge and wet sedge tundra near Bethel, Alaska, U.S.A., Arctic Alpine Res., 22, 175-182, doi:10.2307/1551302, 1990.

Ermakov, A. P. and Starovoitov, A. V.: The use of the ground penetrating radar (gpr) method in engineering-geological studies for the assessment of geological-cryological conditions, Moscow University Geology Bulletin, 65, 422-427, doi:10.3103/S0145875210060116, 2010.

Gacitúa, G., Tamstorf, M. P., Kristiansen, S. M., and Uribe, J. A.: Estimations of moisture content in the active layer in an arctic ecosystem by using ground-penetrating radar profiling, J. Appl. Geophys., 79, 100-106, doi:10.1016/j.jappgeo.2011.12.003, 2012.

Harper, J., Hubbard, A., Ruskeeniemi, T., Claesson Liljedahl, L., Lehtinen, A., Booth, A., Brinkerhoff, D., Drake, H., Dow, C., Doyle, S., Engström, J., Fitzpatrik, A., Frape, S., Henkemans, E., Humphrey, N., Johnson, J., Jones, G., Joughin, I., Klint, K. E., Kukkonen, I., Kulessa, B., Londowski, C., Lindbäck, K., Makahnouk, M., Meierbachtol, T., Pere, T.,Pedersen, K., Petterson, R., Pimentel, S., Quincey, D., Tullborg, E. L., and van As, D.: The Greenland Analogue Project Yearly Report 2010. Svensk Kärnbränslehantering AB, Report SKB R-11-23, 2011.

Isaaks, E. H. and Srivastava, R. M.: An introduction to applied geostatistics, Oxford University Press: Oxford, 1989.

Janza, F. J.: Interaction mechanisms, in: Manual of remote sensing, edited by: Reeves, R. G., Anson, A., and Landen, D., American Society of Photogrammetry: Falls Church, VA, 75-179, 1975.

Johansson, E., Berglund, S., Lindborg, T., Petrone, J., van As, D., Gustafsson, L.-G., Näslund, J.-O., and Laudon, H.: Hydrological and meteorological investigations in a periglacial lake catchment near Kangerlussuaq, west Greenland - presentation of a new multi-parameter data set, Earth Syst. Sci. Data, 7, 93-108, doi:10.5194/essd-7-93-2015, 2015.

Jørgensen, A. and Andreasen, F.: Mapping of permafrost surface using ground-penetrating radar at kangerlussuaq airport, Western Greenland, Cold Reg. Sci. Technol., 48, 64-72, doi:10.1016/j.coldregions.2006.10.007, 2007.

Larsen, J. N., Anisimov, O. A., Constable, A., Hollowed, A. B., Maynard, N., Prestrud, P., Prowse, T. D., and Stone, J. M. R.: Polar regions, in: Climate Change 2014: Impacts, Adaptation, and Vulnerability. Part B: Regional Aspects. Contribution of Working Group II to the Fifth Assessment Report of the Intergovernmental Panel on Climate Change, edited by: Barros, V. R., Field, C. B., Dokken, D. J., Mastrandrea, M. D., Mach, K. J., Bilir, T. E., Chatterjee, M., Ebi, K. L., Estrada, Y. O., Genova, R. C., Girma, B., Kissel, E. S., Levy, A. N., MacCracken, S., Mastrandrea, P. R., and White, L. L., Cambridge University Press, Cambridge, United Kingdom and New York, NY, USA, 1567-1612, 2014.

Lindborg, T., Rydberg, J., Tröjbom, M., Berglund, S., Johansson, E., Löfgren, A., Saetre, P., Nordén, S., Sohlenius, G., Andersson, E., Petrone, J., Borgiel, M., Kautsky, U., and Laudon, H.: Biogeochemical data from terrestrial and aquatic ecosystems in a periglacial catchment, West Greenland, Earth Syst. Sci. Data, 8, 439-459, doi:10.5194/essd-8-439-2016, 2016.

Liu, L., Schaefer, K., Zhang, T., and Wahr, J.: Estimating 19922000 average active layer thickness on the Alaskan North Slope from remotely sensed surface subsidence, J. Geophys. Res., 117, F01005, doi:10.1029/2011JF002041, 2012. 
Neal, A.: Ground-penetrating radar and its use in sedimentology: principles, problems and progress, Earth-Sci. Rev., 66, 261-330, doi:10.1016/j.earscirev.2004.01.004, 2004.

Nelson, F. E. and Anisimov, O. A.: Permafrost zonation in Russia under anthropogenic climate change, Pemafrost Periglac., 4, 137-148, doi:10.1002/ppp.3430040206, 1993.

MacCraken, M. C., Hecht, A. D., Budyko, M. I., and Izrael, Y. A.: Prospects for Future Climate: A special US/USSR Report on Climate and Climate Change, Lewis Publishers: Chelsea, Mich., 1990.

Macdonald, R. W., Harner, T., and Fyfe, J.: Recent climate change in the Arctic and its impact on contaminant pathways and interpretation of temporal trend data, Sci. Total Environ., 342, 5-86, doi:10.1016/j.scitotenv.2004.12.059, 2005.

Maxwell, J. B. and Barrie, L. A.: Atmospheric and climatic change in the Arctic and Antarctic, Ambio, 18, 42-49, 1989.

Pastick, N. J, Jorgenson, M. T., Wylie, B. K., Minsley, B. J., Ji, L., Walvoord, M. A., Smith, B. D., Abraham, J. D., and Rose, J. R.: Extending Airborne Electromagnetic Surveys for Regional Active Layer and Permafrost Mapping with Remote Sensing and Ancillary Data, Yukon Flats Ecoregion, Central Alaska, Permafrost Periglac., 24, 184-199, doi:10.1002/ppp.1775, 2013.

Petrone, J.: Using ground-penetrating radar to estimate sediment load in and around Two BoatLake, western Greenland, Student thesis, Uppsala universitet, Uppsala, available at: http://urn.kb. se/resolve?urn=urn:nbn:se:uu:diva-196291 (last access: 2016), 2013.

Roots, E. F.: Climate change: high latitude regions, Climatic Change, 15, 223-253, doi:10.1007/BF00138853, 1989.
Schuur, E. A. G., McGuire, A. D., Schädel, C., Grosse, G., Harden, J. W., Hayes, D. J., Hugelius, G., Koven, C. D., Kuhry, P.,Lawrence, D. M., Natali, S. M., Olefeldt, D., Romanovsky, V. E., Schaefer, K., Turetsky, M. R., Treat, C. C., and Vonk, J. E.: Climate change and the permafrost carbon feedback, Nature, 250, 171-178, 2015.

Stevens, C. W., Moorman, B. J., Solomon, S. M., and Hugenholtz, C. H.: Mapping subsurface conditions within the near-shore zone of arctic delta using ground penetrating radar, Cold Reg. Sci. Technol., 56, 30-38, doi:10.1016/j.coldregions.2008.09.005, 2009.

van Tatenhove, F., van der Meer, J., and Koster, E.: Implications for deglaciation chronology from new AMS age determinations in central west Greenland, Quaternary Res., 45, 245-253, doi:10.1006/qres.1996.0025, 1996.

Walter, K. M., Zimov, S. A., Chanton, J. P., Verbyla, D., and Chapin, F. S.: Methane bubbling from Siberian thaw lakes as a positive feedback to climate warming, Nature, 443, 71-75, 2006.

Weller, G., Chapin, F. S., Everett, K. R., Hobbie, J. E., Kane, D., Oechel, W. C., Ping, C. L., Reeburgh, W. S., Walker, D., and Walsh, J.: The Arctic Flux Study: a regional view of trace gas release, J. Biogeogr., 22, 365-374, doi:10.2307/2845932, 1995.

Willemse, N. W., Koster, E. A., Hoogakker, B., and van Tatenhove, F. G. M.: A continous record of Holocene eolian activity in Western Greenland, Quaternary Res., 59, 322-334, doi:10.1016/S0033-5894(03)00037-1, 2003.

Wu, T., Wang, Q., and Watanabe, M.: Mapping vertical profile of discontinuous permafrost with ground penetrating radar at Nalaikh depression, Mongolia, Environ. Geol., 56, 1577-1583, doi:10.1007/s00254-008-1255-7, 2009. 